\title{
Is Autologous Stem Cell Transplantation a Risk For Divorce in Lymphoma Survivors?
}

\section{Otolog Kök Hücre Nakli Lenfoma Hastalarında Boşanma İçin Bir Risk Faktörü müdür?}

\author{
Jale Yıldız, Tuğçe Nur Yiğenoğlu, Alparslan Merdin, Bahar Uncu Ulu, Semih Başcı, Tahir Darçın, Samet \\ Yaman, Nuran Ahu Baysal, Dicle İskender, Merih Kızl Çakar, Mehmet Sinan Dal, Fevzi Altuntas
}

SBÜ Dr.A.Y. Ankara Onkoloji EAH, Hematoloji ve Kök Hücre Nakli Kliniği

\section{ÖZET}

GİRIŞ ve AMAÇ: Standart kemoterapi dışında otolog kök hücre nakli (OKHN), relaps/refrakter lenfomalı hastalarda en etkili tedavi seçeneklerinden biridir. Lenfoma tedavisi için OKHN uygulanan hastaların sonraki dönemde sosyal yaşamda, iş hayatında, cinsel yaşamda ve aile ilişkilerinde bazı zorluklar yaşadıkları düşünülmektedir. Bu çalışmanın amacı, lenfoma tedavisi için OKHN uygulanan hastalarda boşanma sıklığını araştırmak ve boşanma üzerinde etkisi olabilecek hasta ve tedavi ilişkili faktörleri değerlendirmektir.

YÖNTEM ve GEREÇLER: Relaps veya refrakter lenfoma nedeniyle OKHN uygulanan, 18 yaş üstü ve remisyonda olan hastalar çalışmaya dahil edildi. Çalışmanın birincil sonlanım noktası OKHN sonrası boşanma sıklığını değerlendirmek, ikincil sonlanım noktası ise boşanmayla ilişkilendirilebilecek faktörleri ortaya koymakt1.

BULGULAR: Çalışmaya dahil edilen 95 hastanın ortanca yaşı 50 (21-69 yaş) idi. Hastaların çoğu erkekti (n: $72, \%$ 75.8). OKHN yapılan hastaların yarısından fazlası (n: 60,\% 63.1) şehir merkezinde yaşarken, 73 (\% 69.5) hasta halen çalışıyordu. Hastalarımızın 80'i (\%84.2) halen evliydi; bu hastalarda ortanca evlilik süresi 30.01 yıl (2.5-48.5 y1l) idi. On beş (\% 15.7) bekar hastadan 4'ü (\% 4.2) OHKN'den sonra boşanmış hastalardan oluşmaktaydı. Cinsiyet, eğitim durumu, çalışma durumu, ikamet yeri, çocuk sahibi olma ve lenfoma tipinin boşanma riski ile ilişkisi olmadığı görüldü.

TARTIŞMA ve SONUÇ: Çalışmamızda OKHN uygulanan lenfoma tanılı hastalarda boşanma oranı\% 4,2 olarak bulunmuştur. Sonuçlarımıza göre lenfoma tipi, cinsiyeti, çalışma durumu ve eğitim durumu boşanma riski ile ilişkili değildi. OKHN öncesi dönemden başlamak üzere aile danışmanlığı verilmesi ve psikoonkoloji konsultasyonunun boşanma sıklığını azaltabileceği düşünülmüştür.

Anahtar Kelimeler: Otolog kök hücre nakli, boşanma, lenfoma

\section{ABSTRACT}

INTRODUCTION: Apart from standard chemotherapy, autologous stem cell transplantation (ASCT) is one of the most effective treatment options in patients with relapse/refractory lymphomas. Lymphoma survivors are thought to experience some difficulties in social life, business life, sexual life and family relations after ASCT. The aim of this study is to investigate the frequency of divorce in patients who underwent ASCT for lymphoma and to evaluate the patient characteristics and the treatment-related factors that may affect the divorce.

METHODS: Patients over 18 years of age with a diagnosis of relapsed or refractory lymphoma who underwent ASCT and in remission were included in the study. The primary endpoint of the study was to evaluate the frequency of divorce after ASCT. The secondary endpoint was to reveal the factors that might be associated with divorce.

RESULTS: The median age of 95 patients included in the study was 50 (21-69 years). Most of the patients were male (n: 72, 75.8\%). More than half of the patients (n: 60, 63.1\%) were living in the city center and $73(69.5 \%)$ patients were still working after ASCT. Eighty (84.2\%) of our patients were still married. The median duration of marriage in these patients was 30.01 years (2.5-48.5 years). Of the $15(15.7 \%)$ single patients, $4(4.2 \%)$ were divorced after ASCT. It was observed that gender, educational status, employment status, place of residence, childbearing and lymphoma type were not associated with divorce rates. 
DISCUSSION AND CONCLUSION: In our study, the rate of divorce was found $4.2 \%$ in lymphoma survivors treated with ASCT. According to our results, lymphoma type, gender, employment status and educational status were not associated with divorce risk. Family counseling and psychooncology consultation starting from the preASCT period can reduce the frequency of divorce.

Keywords: ASCT, divorce, lymphoma, survivor

\section{INTRODUCTION}

Lymphomas are among the top five most common cancer types in the US (1). Although lymphomas are curable cancers, recurrence rates of up to $50 \%$ can be seen depending on prognostic markers such as histological subtype and disease stage $(2,3)$. Apart from standard chemotherapy, autologous stem cell transplantation (ASCT) is one of the most effective treatment options in patients with relapse/refractory lymphoma after high-dose chemotherapy $(4,5)$.

After ASCT, satisfactory disease-free survival times can be achieved, especially in patients with good prognostic features. There are studies investigating if these patients continue their lives as normal as in previous periods. Post-ASCT lymphoma survivors are thought to experience some difficulties in social life, business life, sexual life and family relations. Physical limitations, psychological problems such as depression and anxiety that continue after cancer treatments make it difficult for these patients to adapt to life again (6-8).

The effect of cancer on marital and family ties has been studied most in women with breast cancer. While it was concluded in some studies that breast cancer did not increase the frequency of divorce, the opposite results were obtained in some studies (9-11). The frequency of divorce in lymphoma survivors after ASCT has been the subject of few studies $(12,13)$.

Our aim is to investigate the frequency of divorce in patients who underwent ASCT for relapsed/refractory lymphoma and to evaluate the patient characteristics and the treatmentrelated factors that may affect marital status.

\section{MATERIAL and METHODS \\ Study design}

This study was conducted between January 2020 - May 2020 at Health Sciences University, Ankara Oncology Research and Training Hospital, Department of Hematology. This study was approved by the Ethics Committee of Health Sciences University, Dr. A.Y. Ankara Oncology Training and Research Hospital. All procedures in this study involving human participants were performed in accordance with the 1964 Helsinki Declaration and its later amendments.

Our hospital is a tertiary oncology center, and approximately 150 hematopoietic stem cell transplants (HSCT) are performed annually in transplant clinic. Approximately 200 patients apply to our outpatient clinic daily.

\section{Patients and outcomes}

All patients who applied to our outpatient clinic were evaluated in terms of eligibility to the study. Patients over 18 years of age, with a diagnosis of relapsed or refractory lymphoma who underwent ASCT and in remission were included in the study. Patients currently receiving treatment for relapsed/refractory lymphoma after ASCT were excluded.

The patients who were eligible for the study were informed by the nurse of the hematology outpatient clinic. Informed consent form was given to the patients who wanted to participate in the study. We gave patients enough time to read this form. Patients wishing to participate in the study approved this form. The questionnaire was completed with a face-toface interview in a separate room with those who wanted to participate in the study.

The primary endpoint of the study was to evaluate the frequency of divorce after ASCT. The secondary endpoint was to reveal the factors that might be associated with divorce. Divorce was defined as the fact that the patients were officially separated from their spouses or living in separate houses.

Among the patients participating in the study, those who were married before ASCT were included in the statistical analysis. Those who were single or divorced prior to ASCT were excluded from the analysis.

\section{Statistical analysis}

The data obtained were analyzed through IBM SPSS Statistics for Windows, Version 21.0. Armonk, NY: IBM Corp. Univariate analysis was used to examine whether there was a relationship between divorce and patients' demographic and clinical characteristics. $\mathrm{P}$ value $<0.05$ was considered statistically significant. 


\section{RESULTS}

817 patients who applied to our outpatient clinic were evaluated in terms of eligibility for the study. 102 patients were eligible for the study, but 7 patients did not want to participate in the study.

Table 1. Demographics of the patients

n: $95 \quad \%$

$\begin{array}{lll}\begin{array}{l}\text { Age (years) } \\ \text { Median (range) }\end{array} & 50(21-69) & \\ & & \\ \text { Gender } & & 72.8 \\ \quad \text { Male } & 23 & 24.2 \\ \quad \text { Female } & & \\ & & \\ \text { Place of residence } & 60 & 63.1 \\ \quad \text { City center } & 18 & 18.9 \\ \quad \text { District } & 17 & 17.8 \\ \quad \text { Village } & & \\ & & \\ \text { Marital status } & 15 & 15.8 \\ \quad \text { Single } & 80 & 84.2 \\ \quad \text { Married } & & \\ \quad & & \\ \text { Number of children } & 17 & 17.9 \\ \quad \text { None } & 17 & 17.9 \\ \text { 1 } & 25 & 26.3 \\ 2 & 36 & 37.8 \\ >2 & & \end{array}$

Education level $\begin{array}{lll}\text { Illiterate } & 7 & 7.4\end{array}$ $\begin{array}{lll}\text { Primary } & 58 & 61.1\end{array}$ Secondary $\quad 26 \quad 27.4$ Higher

$4 \quad 4.2$

Occupational status $\begin{array}{lll}\text { Working } & 73 & 69.5\end{array}$

Not working

$29 \quad 30.5$

Type of disease Hodgkin lymphoma $\quad 35 \quad 36.8$ $\begin{array}{lll}\text { Non-Hodgkin } & 60 & 63.2\end{array}$ lymphoma

The median age of 95 patients included in the study was 50 years (21-69 years). Most of the patients were male (n: $72,75.8 \%) .78(82.1 \%)$ patients had at least one child. Considering the education level, $58(61.1 \%)$ patients were primary school graduates, $26(27.4 \%)$ were secondary school graduates, while 4 (4.2\%) patients were graduated from higher education. $7(7.4 \%)$ patients were illiterate. More than half of the patients (n: 60,63.1\%) were living in the city center and $73(69.5 \%)$ patients were still working after ASCT. All patient characteristics are shown in Table 1.

Table 2. Univariate analysis of the patients' characteristics for divorce risk

\begin{tabular}{lcc}
\hline Characteristics & OR $(\mathbf{9 5 \%}$ CI $)$ & $\boldsymbol{P}$ \\
Age (years) & $0.86(0.74-1.05)$ & 0.274 \\
Gender & & \\
Male & Ref & \\
Female & 0.48 & 0.127
\end{tabular}

Place of residence

$\begin{array}{lcc}\text { City center } & \text { Ref } & \\ \text { District } & 0.67 & 0.256 \\ \text { Village } & 0.76 & 0.268\end{array}$

Having children

$\begin{array}{lll}\text { No } & \text { Ref } & \\ \text { Yes } & 0.55 & 0.132\end{array}$

Education level

$\begin{array}{lcc}\text { Illiterate } & \text { Ref } & \\ \text { Primary } & 0.98 & 0.923 \\ \text { Secondary } & 0.89 & 0.761 \\ \text { Higher } & 0.77 & 0.672\end{array}$

Working status

Employed Ref

$\begin{array}{lll}\text { Unemployed } & 0.86 & 0.752\end{array}$

Type of disease Hodgkin Ref

lymphoma $\begin{array}{lll}\text { Non-Hodgkin } & 1.12 & 0.974\end{array}$

lymphoma

Comorbidity

$\begin{array}{lcc}\text { Yes } & \text { Ref } & \\ \text { No } & 0.91 & 0.782\end{array}$

Eighty (84.2\%) of our patients were still married. The median duration of marriage in these patients was 30.01 years (2.5-48.5 years). Of the $15(15.7 \%)$ single patients, $9(9.5 \%)$ were never married,4 (4.2\%) were divorced 
after ASCT and spouses of $2(2.1 \%)$ were deceased.

Considering the factors that may affect divorce; it was observed that gender, educational status, employment status, place of residence, childbearing and lymphoma type were not associated with divorce rates (Table 2).

\section{DISCUSSION}

In studies investigating the relationship between cancer and divorce, patients who underwent ASCT are rarely included (14). This study is one of the rare studies investigating the relationship between ASCT and divorce in lymphoma survivors in a very homogeneous patient group. In our study, the rate of divorce in lymphoma survivors after ASCT was found to be $4.2 \%$.

Some of the cancer patients are cured with current treatments. However, it is a known fact that the treatment process negatively affects the patients' future lives in terms of physical and psychosocial aspects. Disruptions in family ties such as difficulties in returning to work, long-term emotional disturbances, physical limitations due to surgery and/or chemotherapy are also among these problems (15-19).

One of the largest studies investigating divorce risk in cancer survivors has been conducted in the Danish population. In this study, which included patients with hematological malignancies such as leukemia and lymphoma, as well as solid cancers, 46,300 cancer patients were compared with 221,000 control groups. As a result of this study, it was observed that cancer types other than cervical cancer did not pose a risk for divorce (20).

In a study involving 1198 patients, the divorce frequency of young cancer survivors between the ages of 20-39 was investigated. One of the most common diagnoses in this study group was non-Hodgkin lymphoma (20\%). Divorce frequency was higher in cancer survivors compared to the control group (18\% vs $10 \%)$. In the same study, it was observed that emotional disturbances and financial problems posed a risk for divorce, while lymphoma diagnosis did not (14). In our study, the frequency of divorce was lower in lymphoma survivors treated with ASCT compared to this study. While the median age of the patients in our study was 50, all patients in this study were younger than 39 years. At the same time, while all patients in our study were diagnosed with lymphoma, patients from different cancer types were also included in this study. For this reason, we think that the difference in the frequency of divorce may be due to the differences in patient characteristics.

In their 5-year prospective-observational study, Langer et al. found $7 \%$ of the study group divorced after HSCT. In this study, the marital satisfaction perception of the spouses of the patients after HSCT was also measured. It was observed that only gender, not physical or psychosocial characteristics, was related to satisfaction with marriage (13). The frequency of divorce after ASCT in our study was slightly lower than in this study, and according to the results of our study, there was no relationship between gender and divorce risk. It was thought that the cultural differences between the US where the study was conducted and our country, the lower mean age of the patient group in this study and the patient groups requiring chronic treatments after HSCT may cause this difference in the divorce rate.

As far as we know, there is no other study investigating the frequency of divorce in patients who had previously undergone HSCT, in our country. The crude divorce rate in Turkey is $0.18 \%$ by Turkey Statistics Institute report published in 2019 (21). Therefore, when we make a comparison with the frequency of divorce in the general society in our country, it is seen that the rate of divorce in our patients is higher. Although factors such as lymphoma subgroup, gender, employment status are not directly related to divorce; it can be speculated that cancer diagnosis, applied treatments and all the processes experienced may cause an increase in the frequency of divorce.

The most important limitation of our study was that it did not include a control group for comparison. At the same time, the singlecenter nature of our study prevented us from including patients with different sociocultural characteristics. However, our study is one of the rare studies investigating the frequency of divorce in a homogeneous group including lymphoma survivors after ASCT.

\section{CONCLUSION}

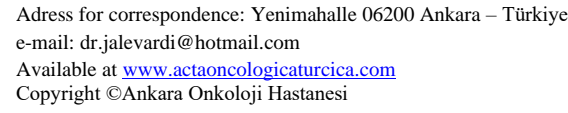


In our study, the frequency of divorce was found to be higher in lymphoma survivors treated with ASCT compared to the general population. According to our results, lymphoma type, gender, employment status and educational status were not associated with divorce risk.

In order to reduce the frequency of divorce, it may be beneficial for each patient and their family to be consulted with psychooncology at the beginning of the treatment, and to be informed about the difficulties and psychiatric burdens of the disease by taking family therapy. The team applying ASCT must also provide clear information to the patient and family about the process. It can be predicted that familial problems and related divorces will be less in patients who receive psychooncological support and know the treatment process well.

Acknowledgments: We would like to thank Gülören Kulkul, nurse of the hematology outpatinet clinic, for her assistance in selecting the appropriate patient for our study.

Conflict of interest: The authors declared that there is no conflict of interest.

Ethics Committee Approval: This study was approved by the Ethics Committee of Health Sciences University, Dr. A.Y. Ankara Oncology Training and Research Hospital. All procedures in this study involving human participants were performed in accordance with the 1964 Helsinki Declaration and its later amendments.

\section{REFERENCES}

1. Siegel RL, Miller KD, Jemal A. Cancer statistics, 2020. CA Cancer J Clin. 2020;70(1):7-30.

2. Feugier $\mathrm{P}$, Van Hoof A, Sebban C, et al. Long-term results of the R-CHOP study in the treatment of elderly patients with diffuse large B-cell lymphoma: a study by the Groupe d'Etude des Lymphomes de l'Adulte. J Clin Oncol. 2005;23(18):4117-26.

3. Reyes F, Lepage E, Ganem G, et al. Groupe d'Etude des Lymphomes de l'Adulte (GELA). ACVBP versus CHOP plus radiotherapy for localized aggressive lymphoma. $\mathrm{N}$ Engl J Med. 2005;352(12):1197-205.

4. Schmitz N, Pfistner B, Sextro M, et al. Aggressive conventional chemotherapy compared with highdose chemotherapy with autologous haemopoietic stem-cell transplantation for relapsed chemosensitive Hodgkin's disease: a randomised trial. Lancet. 2002;359(9323):2065-71.

5. Philip T, Guglielmi C, Hagenbeek A, et al. Autologous bone marrow transplantation as compared with salvage chemotherapy in relapses of

Adress for correspondence: Yenimahalle 06200 Ankara - Türkiye

e-mail: dr.jalevardi@hotmail.com

Available at www.actaoncologicaturcica.com

Copyright $\odot$ Ankara Onkoloji Hastanesi chemotherapy-sensitive non-Hodgkin's lymphoma. N Engl J Med. 1995;333(23):1540-5.

6. Syrjala KL, Langer SL, Abrams JR, Storer BE, Martin PJ. Late effects of hematopoietic cell transplantation among 10-year adult survivors compared with case-matched controls. J Clin Oncol. 2005;23(27):6596-606.

7. Bishop MM, Beaumont JL, Hahn EA, et al. Late effects of cancer and hematopoietic stem-cell transplantation on spouses or partners compared with survivors and survivor-matched controls. J Clin Oncol. 2007;25(11):1403-11.

8. Andrykowski MA, Bishop MM, Hahn EA, et al. Long-term health-related quality of life, growth, and spiritual well-being after hematopoietic stem-cell transplantation. J Clin Oncol. 2005;23(3):599-608.

9. Yildiz F, Alaguney ME. Is early-stage breast cancer a risk for marital-dissolution?. Medical Science and Discovery. 2020;7(7):566-569.

10. Laitala VS, Saarto T, Einiö EK, Martikainen P, Silventoinen K. Early-stage breast cancer is not associated with the risk of marital dissolution in a large prospective study of women. $\mathrm{Br} \mathrm{J}$ Cancer. 2015;113(3):543-7.

11. Kvikstad A, Vatten LJ, Tretli S. Widowhood and divorce in relation to overall survival among middleaged Norwegian women with cancer. Br J Cancer. 1995;71(6):1343-7.

12. Langer SL, Yi JC, Storer BE, Syrjala KL. Marital adjustment, satisfaction and dissolution among hematopoietic stem cell transplant patients and spouses: a prospective, five-year longitudinal investigation. Psychooncology. 2010;19(2):190-200.

13. Langer S, Abrams J, Syrjala K. Caregiver and patient marital satisfaction and affect following hematopoietic stem cell transplantation: A prospective, longitudinal investigation. PsychoOncol. 2003;12:239-253.

14. Kirchhoff AC, Yi J, Wright J, Warner EL, Smith KR. Marriage and divorce among young adult cancer survivors. J Cancer Surviv. 2012;6(4):44150 .

15. Majhail NS. Long-term complications after hematopoietic cell transplantation. Hematol Oncol Stem Cell Ther. 2017;10(4):220-227.

16. Pidala J, Anasetti C, Jim H. Health-related quality of life following haematopoietic cell transplantation: patient education, evaluation and intervention. British journal of haematology. 2010;148:373-385.

17. Syrjala KL, Langer SL, Abrams JR, et al. Recovery and long-term function after hematopoietic cell transplantation for leukemia or lymphoma. JAMA. 2004;291:2335-2343.

18. Schmidt ME, Scherer S, Wiskemann J, Steindorf K. Return to work after breast cancer: The role of treatment-related side effects and potential impact on quality of life. Eur J Cancer Care (Engl). 2019;28(4):13051.

19. Yildiz F, Alaguney ME. Factors associated with the employment status of breast cancer survivors: a single center cross-sectional study. Int J Community Med Public Health. 2020;7(8):2874-2879.

20. Carlsen K, Dalton SO, Frederiksen K, Diderichsen $\mathrm{F}$, Johansen C. Are cancer survivors at an increased 
risk for divorce? A Danish cohort study. Eur J Cancer. 2007;43(14):2093-9.

21. Türkiye İstatistik Kurumu Haber Bülteni. Evlenme ve Boşanma İstatistikleri. 2019; Available from:
http://tuik.gov.tr/preHaberBultenleri.do?id=33708 \# (Accessed date:26.02.2020) 